\title{
An Analysis of Lesson Plans for Learning English in the Senior High School
}

\section{Ni Luh Soma Antari ${ }^{*}$}

1 Jurusan Pendidikan Bahasa Inggris, Universitas Pendidikan Ganesha, Singaraja, Indonesia

\section{ART ICLE IN F O}

\section{Article history}

Received February 02, 2021

Revised February 23, 2021

Accepted March 20, 2021

Available online April 25, 2021

Kata Kunci:

RPP, Pembelajaran Online, Bahasa

Inggris

\section{Keywords:}

Lesson Plan, Online Learning,

English

\section{A B S T RAK}

Penyusunan RPP untuk pembelajaran bahasa Inggris merupakan aspek penting yang harus dilakukan, sebelum melakukan aspek belajar mengajar namun tidak semua guru mampu melakukan hal tersebu. Penelitian ini bertujuan untuk menganalisis masalah yang dilakukan oleh guru bahasa Inggris di SMA. Penelitian ini merupakan penelitian kualitatif. Subjek dalam penelitian ini adalah seorang guru bahasa Inggris. Data langkah-langkah penyusunan RPP pembelajaran bahasa Inggris melalui google classroom dan permasalahannya dikumpulkan melalui kuesioner. Pengumpulan data dilakukan dengan memberikan dua kuesioner kepada guru bahasa Inggris. Data yang diperoleh dianalisis secara deskriptif dan kualitatif. Hasil penelitian menunjukkan bahwa langkah-langkah yang dilakukan dalam penyusunan RPP pembelajaran bahasa Inggris mengikuti 5 aspek RPP Kurikulum 2013 yaitu tujuan pembelajaran, materi pembelajaran, kegiatan pembelajaran, media dan sumber pembelajaran, penilaian pembelajaran. Terdapat 7 permasalahan yang ditemukan ketika mereka menyusun RPP pembelajaran bahasa Inggris diantaranya ialah yang terjadi pada aspek tujuan pembelajaran, kegiatan pembelajaran, dan penilaian pembelajaran. Berdasarkan hasil penelitian tersebut dapat disimpulkan bahwa RPP pembelajaran bahasa Inggris dapat digunakan dalam proses pembelajaran online.

\begin{abstract}
A B S T R A C T
Preparation of lesson plans for learning English is an important aspect that must be done, before carrying out aspects of teaching and learning, but not all teachers are able to do this. This study aims to analyze the problems carried out by English teachers in high school. This research is qualitative research. The subject in this study was an English teacher. Data on the steps of preparing the RPP for learning English through google classroom and the problems were collected through a questionnaire. Data was collected by giving two questionnaires to the English teacher. The data obtained were analyzed descriptively and qualitatively. The results showed that the steps taken in the preparation of Indonesian language learning lesson plans followed 5 aspects of the 2013 curriculum lesson plans, namely learning objectives, learning materials, learning activities, media, and learning resources, learning. There were 7 problems that were found when they compiled the lesson plans for learning English, including those that occurred in the aspects of learning objectives, learning activities, and learning. So, it can be said that the lesson plan for learning English can be used in the online learning process.
\end{abstract}

\section{Introduction}

Adapting the situation into online learning makes the aspect of learning English becomes important, especially in the context of English as a foreign language. Mastering strategies and planning a series of activities to support online learning platforms is a must. In this case, the preparation of lesson plans for learning English is an important aspect that must be done, before carrying out aspects of teaching and learning. There are two important points why lesson planning is important, namely lesson plans are used as a guide for teachers in teaching and lesson plans are related to teacher-student relationships. Teachers who have made plans show their commitment to teaching and will get a positive response from students. Every educator in the education unit is required to compile a complete and 
systematic lesson plan so that learning takes place interactively, inspiring, fun, challenging, efficient, motivating. students to participate actively, and provide sufficient space for the initiative, creativity, and independence following the talents, interests, and physical and psychological development of students. RPP has several components in it, such as indicators, learning methods, learning approaches, learning objectives, learning activities and evaluations, teaching materials, and time allocation. Moreover, adapting the situation into online learning due to Covid-19 makes aspects of preparing RPP even more important. Several applications are used for the online teaching and learning process, such as Zoom App, Google Classroom, Google Meet, Schoology, and other supporting learning platforms. (Baber, 2020; Roni Hamdani \& Priatna, 2020; Setiawan \& Wicaksono, 2020; Sukmawati \& Nensia, 2019; Wahyudi \& Agung, 2021).

Based on pre-observations conducted in several schools in Buleleng Regency, one of the platforms commonly used to facilitate online learning is Google Classroom. Google Classroom is part of a Google product that was first introduced in 2014 to help the online learning process in an interactive learning environment (Mafa, 2018; Setyoko \& Indriaty, 2018). However, apart from the advantages offered, this platform also has some disadvantages that need to be considered. Some of the disadvantages of using Google Classroom in facilitating the first learning process are that supporting facilities and infrastructure are needed such as computers and internet access to support the online learning process. Unfortunately, not all students or teachers can afford this kind of facility. Therefore, this can be a problem in the learning process. Second, because teachers are not physically present beside students, they are expected to learn more independently by actively learning through books or the internet. This limited interaction and monitoring may affect their understanding of the material. Given the limited role of the teacher, it is important to ensure that the teacher has prepared the teaching and learning process for learning English to the fullest.

Based on the observations that have been made, one of the schools in Buleleng Regency that uses google classroom in learning English is SMA Negeri 3 Singaraja. The choice of using google classroom to facilitate online learning in these difficult times is due to the advantages and disadvantages of using it, which are interesting to analyze. Given the importance of English and the sudden changes in the teaching and learning process, it is important to investigate the aspects of preparing lesson plans through google classroom at SMA Negeri 3 Singaraja as one of the schools that uses a platform in teaching English. In addition, this school has also implemented the K-13 curriculum, which uses a scientific approach in its learning activities that helps teachers develop learning activities by separating the process into several detailed steps. There has been no in-depth research on the use of Google Classroom for assignment submission activities, but also as the main application in supporting online teaching and learning activities and media in conducting the assessment process during online learning.

Several studies that are relevant to this research seem to have been carried out by (Kurniawati et al., 2019) found that the learning process using google classroom students was in the very good category, student learning outcomes were in the moderate category, there were differences in learning outcomes between male and female students, and student responses were in the very high category. Then the research conducted by (Wicaksono, 2020) found that the use of google classroom in cooperative learning strategies was also assessed as being able to foster activeness, the ability to think, enthusiasm, and interest of students because with the appropriate media and learning strategies, the learning process was no longer boring. Other research was also conducted and found that teachers were able to invite students to join and study the content of teaching materials and evaluation assessments in the LMS-google classroom enthusiastically and enthusiastically (Fauziah et al., 2019; Prayitno \& Mardianto, 2020; Sudibjo, 2019; Xue et al., 2021; Yunitasari \& Hanifah, 2020). The purpose of this study is to analyze the problems carried out by English teachers in Senior High School.

\section{Method}

This study uses a qualitative design as a research design (Sugiyono, 2016). The subject in this study was an English teacher from SMA N 3 Singaraja. The English teacher at SMA N 3 Singaraja was chosen because the teacher has been using google classroom for the preparation of lesson plans since August-October 2020. Data on the steps for preparing English learning lesson plans through google classroom and the problems were collected through questionnaires. Data was collected by giving two questionnaires to the English teacher at SMAN 3 Singaraja. The data obtained were analyzed descriptively and qualitatively. Data about the steps that have been taken by the English teacher in preparing the lesson plans for learning English through google classroom and data about the problems faced by the English teachers in preparing the lesson plans were collected through a questionnaire. The questionnaire contains 20 items and is developed into 5 aspects. The twenty items are described from five aspects of lesson plans, namely: 1) learning objectives, 2) learning materials, 3) learning activities, 4) learning media and 
resources, and 5) learning assessment. Regarding the validity of the instrument, it takes two experts to check the feasibility of the instrument.

\section{Results and Discussion}

Before analyzing the data, please note that the RPP for learning English through Google Classroom already exists. In this study, the lesson plans that had been written or prepared by the English teacher were re-analyzed. The steps for preparing lesson plans during the pandemic through google classroom were analyzed qualitatively. Regarding the results of the questionnaires and interviews, several important findings were found as follows.

The English teacher explains that the learning objectives are expected to be achieved with four elements including Audience (A), Behaviour (B), Condition (C) dan Degree Of Attainment (D) (Oktafianti, 2019; Maba, 2017; Astria, 2013). In this case, the learning objectives made by the teacher can be seen in Table 1.

Table 1. Learning Objectives Made by Teachers

\begin{tabular}{|c|c|}
\hline Lesson Plan Topics & Learning Objectives \\
\hline Compliment and Congratulations & $\begin{array}{l}\text { 1. The students (A) are able to identify (B) the } \\
\text { expression of compliment and congratulations (C) } \\
\text { correctly (D) }\end{array}$ \\
\hline Intentions & $\begin{array}{l}\text { 1. The students (A) are able to identify (B) the } \\
\text { expression of asking and giving intention (C) } \\
\text { correctly (D) } \\
\text { 1. The students (A) are able to apply (B) the } \\
\text { expression of asking and giving attention (C) } \\
\text { correctly (D) }\end{array}$ \\
\hline Descriptive Text & $\begin{array}{l}\text { 1. The students (A) are able to identify (B) the } \\
\text { pictures of Pink Beach (C) correctly (D) } \\
\text { 2. The students (A) are able to determine (B) social } \\
\text { function, text structure and language features of } \\
\text { descriptive text (C) correctly (D) } \\
\text { 1. The students (A) are able to create (B) short } \\
\text { descriptive text about nearby places (C) correctly } \\
\text { (D) }\end{array}$ \\
\hline Announcement & $\begin{array}{l}\text { 1. The students (A) are able to determine (B) social } \\
\text { function, generic structure and language features } \\
\text { from the announcement texts (C) correctly (D) } \\
\text { 1. The students (A) are able to create (B) short } \\
\text { announcement with social function, text structute } \\
\text { and language features (C) appropriate in context } \\
\text { (D). }\end{array}$ \\
\hline
\end{tabular}

In addition to stating the learning objectives, the English teacher was also asked whether to link the learning objectives with core competencies and basic competencies. In the example above, the English teacher. In the example above, the English teacher has linked learning objectives with knowledge (noun), skills (to identify, define, and apply), and attitudes (correctly and in context).

The second step taken by the English teacher is to organize, compile, and develop teaching materials or teaching materials. Learning materials are any collection of material including animate and inanimate objects and human and non-human resources that English teachers use in teaching and learning situations to help achieve the desired learning objectives (Bin-Hady \& Abdulsafi, 2019). In terms of teaching materials made by the teacher can be seen in Table 2.

Table 2. Aspects of Learning Materials in Lesson Plans Prepared by Teachers

\begin{tabular}{cl}
\hline Topics & \multicolumn{1}{c}{ Learning Materials } \\
\hline & $\begin{array}{l}\text { Congratulations are words expressing praise for an } \\
\text { achievement or good wishes on a special occasion. }\end{array}$ \\
& $\begin{array}{l}\text { Meanwhile, Compliment is expression of praise or } \\
\text { admiration. }\end{array}$ \\
\hline
\end{tabular}




\begin{tabular}{|c|c|}
\hline Topics & Learning Materials \\
\hline Intentions & $\begin{array}{l}\text { An intention is an idea that you plan (or intend) to carry } \\
\text { out. A plan is arrangement for doing something } \\
\text { considered in advance. }\end{array}$ \\
\hline Descriptive Text & $\begin{array}{l}\text { A descriptive text is a text which describes a place or a } \\
\text { person or a thing. }\end{array}$ \\
\hline Announcement & $\begin{array}{l}\text { An announcement is a public statement, containing } \\
\text { information about an event that has happened or is } \\
\text { going to happen. }\end{array}$ \\
\hline
\end{tabular}

The third step is to organize learning activities based on learning materials, learning methods, and learning techniques. Learning activities are activities designed or used by English teachers to create or create learning conditions for learning. The learning method refers to any activity that is intentionally carried out, or the resources provided, to assist the learning process. While the learning techniques include all strategies in applying methods or procedures in learning English. Learning activities, methods, and techniques prepared by the teacher can be seen in Table 3.

Table 3. Learning Activities, Learning Methods, and Learning Techniques in Lesson Plans Prepared by Teachers (Topic: Compliment and Congratulations)

\begin{tabular}{|c|c|c|}
\hline Learning Activities & Learning Method & Learning Technique \\
\hline $\begin{array}{l}\text { Pre-Activity } \\
\text { 1. The teacher greets the students. } \\
\text { 2. The teacher checks student } \\
\text { attendance. } \\
\text { 3. The teacher states the learning } \\
\text { objectives. } \\
\text { Main Activity } \\
\text { 1. The teacher gives some pictures to } \\
\text { the students. } \\
\text { 2. The teacher asks students about the } \\
\text { pictures by using some guide } \\
\text { questions related to the material. } \\
\text { 3. The teacher gives a brief explanation } \\
\text { of the material and also provides a } \\
\text { video from youtube to clarify the } \\
\text { explanation } \\
\text { (https://youtu.be/aO6iOhVBDzc). } \\
\text { 4. The teacher shows the text "Pink } \\
\text { Beach" and asks all students to } \\
\text { discuss it together. } \\
\text { 5. The teacher gives the task to the } \\
\text { students to make a short written } \\
\text { descriptive text about a place around } \\
\text { them. } \\
\text { Post Activity } \\
\text { 1. The teacher invites several students } \\
\text { to complete the task. } \\
\text { 2. The teacher provides feedback about } \\
\text { the lesson. } \\
\text { 3. The teacher ends the class by saying } \\
\text { goodbye. }\end{array}$ & $\begin{array}{l}\text { Communicative Language } \\
\text { Teaching Method (CLT) }\end{array}$ & $\begin{array}{l}\text { Discussion and Giving Task } \\
\text { through Google Classroom }\end{array}$ \\
\hline
\end{tabular}

The fourth step is to choose learning media based on learning objectives. Learning media are tools in the form of physical and non-physical used in delivering learning materials to students to be more effective and efficient, so that learning materials are accepted more quickly and attract students' attention, interest, and motivation (Oroujlou \& Vahedi, 2016; Lestiyanawati \& Widyantoro, 2020). Meanwhile, learning resources are generally understood as texts, videos, software, and other materials that help students meet learning expectations as defined in the curriculum. After determining learning resources 
based on learning objectives, the English teacher continues to select learning media and learning resources based on learning activities, and learning methods/techniques. Learning media and learning resources used by teachers in the prepared lesson plans can be seen in Table 4.

Table 4. Learning Media and Learning Resources Used by Teachers

\begin{tabular}{lcc}
\hline \multicolumn{1}{c}{ Topics } & Learning Media & Learning Sources \\
\hline Compliment and Congratulations & WhatsApp, Google Classroom, & English Book from \\
Intentions & Youtube & Kemendikbud (2017) \\
Descriptive Text & & \\
Announcement & & \\
\hline
\end{tabular}

The fifth step is to choose the type of assessment based on the learning objectives. Learning assessment is a method to measure how much knowledge and skills a learner has acquired in learning English, which consists of Attitude Assessment, Knowledge Assessment, dan Skills Assessment (Bin-Hady \& Abdulsafi, 2019; Suryana, 2019). Assessment technique refers to a quick and easy formative evaluation method that helps English teachers check students' understanding. The final step is to choose the appropriate type and assessment technique for the online learning platform. Aspects of learning assessment in the lesson plans prepared by the teacher can be seen in Table 5.

Table 5. Aspects of Learning Assessment in Lesson Plans Prepared by Teachers

\begin{tabular}{lccc}
\hline \multirow{2}{*}{ Topics } & \multicolumn{3}{c}{ Learning Assessment } \\
\cline { 2 - 4 } \multicolumn{1}{c}{ Attitude } & Knowledge & Skills \\
\hline Compliment and & & Measuring their & \\
Congratulations & Observations during the & By answering \\
Intentions & learning process. & participation & during class \\
Descriptive Text & & questions. \\
Announcement & & & \\
\hline
\end{tabular}

Based on Table 5, it can be seen that from the four topics the teacher met the learning assessment with the same assessment. In attitude assessment, the teacher uses observation during the learning process. In terms of knowledge assessment, the teacher measures students during the learning process in the classroom. In addition, teachers measure students' skills by answering questions. By carrying out identical activities in the learning assessment process, teachers can assess student learning consistently.

In preparing the lesson plans for learning English through google classroom at SMAN 3 Singaraja, the English teacher found several obstacles. From the 20 questionnaire items, the teacher mentioned 7 problems found in 1) Connecting learning objectives with core competencies, 2) Connecting learning objectives with basic competencies, 3) Organizing learning activities based on learning materials, 4) Organizing learning activities based on learning methods and techniques, 5) Choose the type of assessment based on the learning objectives, 6) Choose the assessment technique based on the learning objectives, and 7) Choose the appropriate type and assessment technique for online learning.

English teachers have difficulty in linking learning objectives with core competencies and basic competencies. Teachers are aware of the difficulty of linking learning objectives with core competencies because it is not easy to know whether students can understand, or apply learning objectives. Learning objectives with basic competencies are also considered an obstacle by teachers because meeting learning objectives when online learning is very difficult to do. Determination of goals or targets in the preparation of lesson plans is an important starting point so that it can be right on target in online learning. In preparing the lesson plans, it is a conscious effort made by the teacher before carrying out classroom learning in the form of clear procedures to achieve goals, to obtain satisfactory results (Arseni et al., 2020; Husna \& Nurhayati, 2018; Mardiana et al., 2020; Suciati \& Astuti, 2019). In addition, teachers have the opportunity to think deeply about the subject matter, including the way the subject matter is represented in certain textbooks or in aspects of the curriculum as standards and benchmarks (Shen et al. 2007; Apsari, 2013; Qothrunnada, 2017).

In other aspects, it was also found that the problems faced by teachers were in the aspect of organizing learning activities based on teaching materials and organizing learning activities based on learning methods and techniques. These problems occur because of the problems experienced by teachers due to online learning, so they must adjust learning activities so that learning can run well. Concerning learning activities, it is important to do so that students understand and increase their potential in learning through appropriate activities. Good quality lesson plans are used to find out what the teacher 
has prepared for them. A good lesson plan should fit the student and what the curriculum or syllabus expects. It can be said that lesson plans are teaching plans developed by a teacher based on the interests and needs of students as well as curriculum objectives through deep and precise thinking. Developing a lesson plan can be difficult and requires effort, effort, and time to achieve. In terms of implementing effective learning, every activity in the classroom must be regulated in a directed manner. This makes lesson planning a fundamental stage in the teaching-learning cycle.

Another aspect that becomes a problem is the aspect of learning assessment. This aspect is the main problem found by the teacher, because the three learning assessment items were encountered as a problem by the teacher. In the step of selecting the type of assessment based on the learning objectives, it was mentioned as a problem by the teacher because they had difficulty in choosing the type of assessment. In online learning, it is very difficult to assess attitudes and skills. An English teacher must design lesson plans as a teaching guide, especially in evaluating the learning process so that they can evaluate whether the objectives of the material can be achieved or not. If the teacher does not prepare well, then the teaching will not go well. In the next problem found problems that occur in the assessment aspect, which is related to the assessment used due to online learning. This must be resolved, because of the importance of effective assessment used in lesson plans. Assessment is one element that must be considered so that the teaching and learning process can take place successfully. RPP is an important element in the process of meeting national content standards and optimizing teaching and learning outcomes in the classroom, which is related to a combination of learning goal design, teaching, modeling, checking understanding, reteaching and teacher self-reflection (assessment aspect).

\section{Conclusion}

English learning lesson plans can be used in the online learning process. The lesson plan developed by the teacher is developing well because it contains 5 aspects of the lesson plan including learning objectives, learning materials, learning activities, media and learning resources, learning assessment. There are 7 problems for teachers in preparing lesson plans in the preparation of lesson plans for learning English, including: linking learning objectives with core competencies, linking learning objectives for basic competencies, organizing learning activities based on learning materials, organizing learning activities based on learning methods and techniques, choosing the type of assessment based on learning objectives, selecting assessment techniques based on learning objectives, and selecting appropriate types and assessment techniques for online learning platforms.

\section{References}

Apsari, Y. (2013). Teachers' Problems and Solutions in Implementing Curriculum 2013. Journal of STKIP Siliwangi Bandung, 11-23.

Arseni, P. A. E., Lasmawan, W., \& Suarni, K. (2020). Pengembangan Rencana Pelaksanaan Pembelajaran (RPP) Tema Tugaskusehari-Hari Kelas II SD Berbasis Kecakapan Belajar Dan Berinovasi Abad 21. Jurnal Pendidikan Dasar Indonesia, 4(1), https://doi.org/https://doi.org/10.23887/jpdi.v4i1.3079.

Astria, W. J. (2013). The Implementation of Curriculum 2013 in Teaching English at SMPN 8 Padang. Journal Ilmiah Pendidikan Scholastic, 1, 33-41.

Baber, H. (2020). Determinants of students' perceived learning outcome and satisfaction in online learning during the pandemic of COVID19. Journal of Education and E-Learning Research, 7(3), 285-292. https: //doi.org/10.20448/JOURNAL.509.2020.73.285.292.

Bin-Hady, W. R. A., \& Abdulsafi, A. S. T. (2019). How Can I Prepare an Ideal Lesson-Plan? SSRN Electronic Journal, 7(4). https://doi.org/10.2139/ssrn.3434031.

Fauziah, U. N. El, Suryani, L., \& Syahrizal, T. (2019). Penerapan Google Classroom Dalam Pembelajaran Bahasa Inggris Kepada Guru-Guru Bahasa Inggris Smp Di Subang. Abdimas Siliwangi, 2(2), 183. https://doi.org/10.22460/as.v2i2p183-191.3281.

Husna, N., \& Nurhayati, N. (2018). Pengembangan Perangkat Scientific berbasis multirepresentasi untuk menunjang pembelajaran matematika dalam kurikulum 2013. Jurnal Pendidikan Matematika Indonesia, 3(2), 74-80. https://doi.org/https://dx.doi.org/10.26737/jpmi.v3i2.729.

Kurniawati, M., Santanapurba, H., \& Kusumawati, E. (2019). Penerapan Blended Learning Menggunakan Model Flipped Classroom Berbantuan Google Classroom Dalam Pembelajaran Matematika SMP. EDU-MAT: Jurnal Pendidikan Matematika, https://doi.org/10.20527/edumat.v7i1.6827.

Lestiyanawati, R., \& Widyantoro, A. (2020). Strategies and Problems Faced by Indonesian Teachers in 
Conducting E- Learning System During COVID-19 Outbreak. CLLiENT Journal (Journal of Culture, Literature, Linguistics and English Teaching), 2(1), 71-82.

Maba, W. (2017). Teachers' Perception on the Implementation of the Assessment Process in 2013 Curriculum. International Journal of Social Sciences and Humanities, 1(2), 1-9.

Mafa, K. R. (2018). Capabilities of Google Classroom as a Teaching and Learning Tool in Higher Education. IJSTE: International Journal of Science Technology \& Engineering, 5(5), 30-34.

Mardiana, D., Abbas, E. W., \& Mutiani, M. (2020). The Lesson Planning of Social Studies Learning in SMPN 1 Banjarbaru. The Innovation of Social Studies Journal, 2(1), 25-32.

Oktafianti, T. (2019). An Analysis of Lesson Plan made by an English Teacher referring to Curriculum 2013 at MTS Al-Qur'an Harsallakum Bengkulu in Academic Year 2018/2019. State Institute for Islamic Studies (IAIN) Bengkulu.

Oroujlou, N., \& Vahedi, M. (2016). Motivation, attitude, and language learning. Procedia - Social and Behavioral Sciences, 29(December 2011), 994-1000. https: //doi.org/10.1016/j.sbspro.2011.11.333.

Prayitno, P., \& Mardianto, M. F. F. (2020). Peningkatan Hasil Evaluasi Pembelajaran Daring Saat Pandemi Covid-19 Berdasarkan Media Powerpoint Interaktif. MUST: Journal of Mathematics Education, Science and Technology, 5(2), 171-181. https://doi.org/http://doi.org/10.30651/must.v5i2.6119.

Qothrunnada, R. (2017). The Implementation of Lesson Plan in Teaching Practice by English Education Department Students of Universitas Muhammadiyah Yogyakarta. Universitas Muhammadiyah Yogyakarta.

Roni Hamdani, A., \& Priatna, A. (2020). Efektifitas Implementasi Pembelajaran Daring (Full Online) Dimasa Pandemi Covid- 19 Pada Jenjang Sekolah Dasar Di Kabupaten Subang. Didaktik: Jurnal Ilmiah PGSD STKIP Subang, 6(1), 1-9. https://doi.org/10.36989/didaktik.v6i1.120.

Setiawan, D., \& Wicaksono, S. L. (2020). Evaluasi Usability Google Classroom Menggunakan System Usability Scale. Walisongo Journal of Information Technology, 2(1), 71. https://doi.org/10.21580/wjit.2020.2.1.5792.

Setyoko, S., \& Indriaty, I. (2018). Implementasi Pembelajaran Blended Learning Berbasis Media Google Classrom Terhadap Hasil Belajar Mahasiswa Pendidikan Fisika. GRAVITASI: Jurnal Pendidikan Fisika Dan Sains, 1(2), 5-10.

Shen, J., Poppink, S., Cui, Y., \& Fan, G. (2007). Lesson Planning : A Practice of Professional Responsibility and Development. Educational Horizons.

Suciati, R., \& Astuti, Y. (2019). Analisis Rencana Pelaksanaan Pembelajaran (Rpp) Mahasiswa Calon Guru Biologi. Edusains, 8(2), 192-200. https://doi.org/10.15408/es.v8i2.4059.

Sudibjo, A. (2019). Penggunaan Media Pembelajaran Ipa Berbasis Google Classroom Pada Materi Alat Optik Untuk Meningkatkan Respons Motivasi Dan Hasil Belajar Siswa Di Smp Negeri 4 Surabaya. $\begin{array}{llll}\text { Jurnal Education } & \text { and }\end{array}$ https://doi.org/https://doi.org/10.37081/ed.v7i3.1272.

Sugiyono. (2016). Metode Penelitian Kualitatif, Kuantitatif, dan R\&D. Alfabeta.

Sukmawati, S., \& Nensia, N. (2019). The Role of Google Classroom in ELT. International Journal for Educational and Vocational Studies, 1(2), 142-145. https: //doi.org/10.29103/ijevs.v1i2.1526.

Suryana, A. (2019). An Analysis of English Teachers' Ability in Designing Lesson Plan Based on 2013 Curriculum at SMK Muhammadiyah 3 Pekanbaru. State Islamic University of Sultan Syarif Kasim Riau.

Wahyudi, I. M. D., \& Agung, A. A. G. (2021). Pengembangan Video Pembelajaran Berbasis Tri Hita Karana Pada Muatan Pelajaran IPS Kelas V SD. Jurnal Pedaagogi Dan Pembelajaran, 4(1), 49-58. https://doi.org/http://dx.doi.org/10.23887/jp2.v4i1.32105.

Wicaksono, M. D. (2020). Pemanfaatan Google Classroom Dalam Strategi Pembelajaran Kooperatif Pada Mata Pelajaran IPS Kelas VIII. Jurnal Ilmu Ilmu Sosial, 17(1), 234-242. https://doi.org/https://doi.org/10.29100/insp.v17i1.1568.

Xue, Q., Xie, X., Liu, Q., Zhou, Y., Zhu, K., Wu, H., Wan, Z., Feng, Y., Meng, H., Zhang, J., Zuo, P., \& Song, R. (2021). Knowledge, attitudes, and practices towards COVID-19 among primary school students in Hubei Province, China. Children and Youth Services Review, 120(August), 105735. https://doi.org/10.1016/j.childyouth.2020.105735.

Yunitasari, R., \& Hanifah, U. (2020). Pengaruh Pembelajaran Daring terhadap Minat Belajar Siswa pada Masa COVID 19. Edukatif: Jurnal Ilmu Pendidikan, 2(3), 236-240. https://doi.org/10.31004/edukatif.v2i3.142 